\title{
Smokers and ex-smokers with chronic stable asthma did not respond to high dose oral corticosteroids
}

Chaudhuri R, Livingston $E$, McMahon $A D$, et al. Cigarette smoking impairs the therapeutic response to oral corticosteroids in chronic asthma. Am J Respir Crit Care Med 2003;168:1308-11.

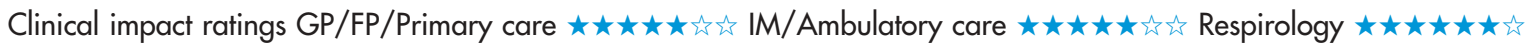

In patients with chronic stable asthma, is bronchodilator and symptomatic response to high dose oral corticosteroids affected by smoking status?

\section{METHODS}

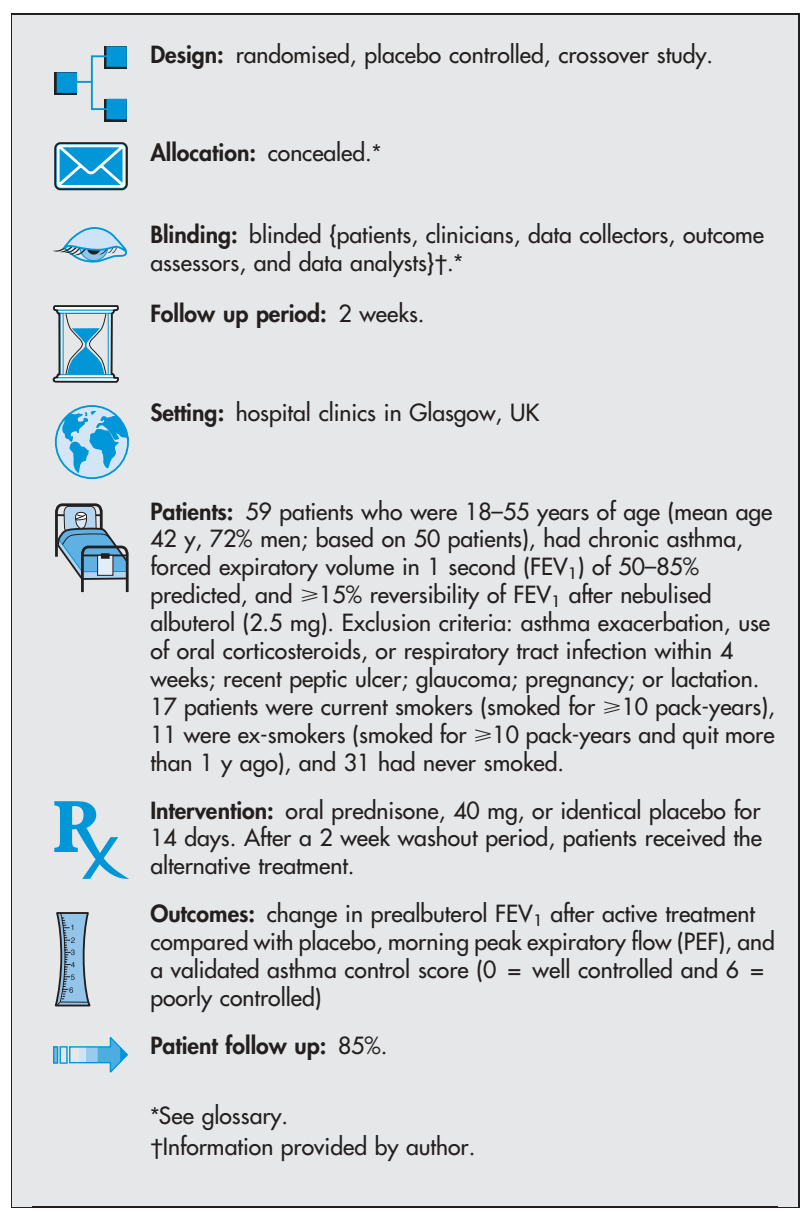

\section{MAIN RESULTS}

Patients who had never smoked had improvement in prealbuterol $\mathrm{FEV}_{1}$ and asthma control scores with prednisone compared with placebo, whereas smokers and ex-smokers did not (table). Morning PEF improved in never-smokers and ex-smokers but not current smokers (table).

\section{CONCLUSION}

In patients with chronic stable asthma, a 2 week course of prednisolone improved $\mathrm{FEV}_{1}$ and asthma control scores in neversmokers, but not in smokers or ex-smokers. For correspondence: Professor N C Thomson, Western Infirmary, Glasgow, UK. n.c.thomson@clinmed.gla.ac.uk

Source of funding: National Asthma Campaign.
Response to prednisolone $v$ placebo according to smoking status in patients with stable chronic asthma*

\begin{tabular}{|c|c|c|c|}
\hline \multirow[b]{2}{*}{ Outcomes $\dagger$} & \multicolumn{3}{|c|}{ Mean difference (95\% confidence interval) } \\
\hline & $\begin{array}{l}\text { Current smokers } \\
(n=14)\end{array}$ & $\begin{array}{l}\text { Ex-smokers } \\
(n=10)\end{array}$ & $\begin{array}{l}\text { Never-smokers } \\
(n=26)\end{array}$ \\
\hline $\begin{array}{l}\text { Change in } \mathrm{FEV} \\
\text { prealbuterol (ml) }\end{array}$ & $\begin{array}{l}47 \\
(-148 \text { to } 243)\end{array}$ & $\begin{array}{l}143 \\
(-223 \text { to } 510)\end{array}$ & $\begin{array}{l}237 \\
\text { (43 to } 431 \text { ) }\end{array}$ \\
\hline $\begin{array}{l}\text { Change in } \\
\text { morning PEF } \\
(\mathrm{l} / \mathrm{m})\end{array}$ & $\begin{array}{l}6.5 \\
(-13 \text { to } 26)\end{array}$ & $\begin{array}{l}29.1 \\
(2.3 \text { to } 56)\end{array}$ & $\begin{array}{l}36.8 \\
(11.4 \text { to } 62)\end{array}$ \\
\hline $\begin{array}{l}\text { Asthma control } \\
\text { score } \neq\end{array}$ & $\begin{array}{l}-0.05 \\
(-0.7 \text { to } 0.6)\end{array}$ & $\begin{array}{l}-0.61 \\
(-1 \text { to } 0.2)\end{array}$ & $\begin{array}{l}-0.72 \\
(-1 \text { to }-0.3)\end{array}$ \\
\hline
\end{tabular}

${ }^{*} \mathrm{FEV}_{1}=$ forced expiratory volume in 1 second, $\mathrm{PEF}=$ peak expiratory flow.

tChange after corticosteroids compared with placebo.

$\ddagger 6$ point scale, $0=$ well controlled and $6=$ poorly controlled.

\section{Commentary}

O ops! That's how asthma researchers are responding to the results of the study by Chaudhuri et al. Several decades of randomised controlled trials about corticosteroid treatment in asthma have shown how exquisitely effective they are (NNTs of about 3 for preventing exacerbations), ${ }^{1}$ but only in non-smokers.

Generalisability is "the degree to which the results of a study can be extrapolated to other circumstances, in particular to routine health care situations." 2 Seeing a patient who has respiratory symptoms and smokes is a routine (predictable!) healthcare situation. Imagine a situation where the most effective treatment for the most common chronic respiratory disease gets it wrong on generalisability.

What can we learn from this? We'll still give steroids for asthma because the confidence intervals for the effect size are sufficiently wide to indicate that there are definite responders within the smoking population. We'll be less enthusiastic about the response, however, and urgently ask clinical trialists to evaluate long acting $\beta$ agonists and inhaled corticosteroids for efficacy in patients with asthma who smoke. The results also emphasise more than ever the need for practitioners to be expert in smoking cessation techniques.

The underlying biological mechanisms of smoking related corticosteroid resistance in asthma will teach us a lot about asthma, and early data suggest a different inflammatory process resembling non-eosinophilic asthma. ${ }^{3}$ Some mischievous types will try to explain this away by invoking definitions of asthma and COPD. But that's all smoke and mirrors.

Peter G Gibson, MD Hunter Medical Research Institute, John Hunter Hospital Newcastle, New South Wales, Australia

1 Powell H, Gibson PG. Inhaled corticosteroid doses in asthma: an evidencebased approach. Med J Aust 2003;178:223-5.

2 Cochrane Reviewers Handbook 2003 (version 4.2) http://

www.cochrane.dk/cochrane/handbook/hbookGeneralisability.htm

3 Chalmers GW, MacLeod KJ, Thomson L, et al. Smoking and airway inflammation in patients with mild asthma. Chest 2001;120:1917-22. 